Journal of Tropical Ecology

http://journals.cambridge.org/TRO

Additional services for Journal of Tropical Ecology:

Email alerts: Click here

Subscriptions: Click here

Commercial reprints: Click here

Terms of use : $\underline{\text { Click here }}$

\title{
The role of earthworms in nitrogen and solute retention in a tropical forest in Sabah, Malaysia: a pilot study
}

Sarah Johnson, Arshiya Bose, Jake L. Snaddon and Brian Moss

Journal of Tropical Ecology / Volume 28 / Issue 06 / November 2012, pp 611 - 614

DOI: $10.1017 / S 0266467412000624$, Published online:

Link to this article: http://journals.cambridge.org/abstract_S0266467412000624

How to cite this article:

Sarah Johnson, Arshiya Bose, Jake L. Snaddon and Brian Moss (2012). The role of earthworms in nitrogen and solute retention in a tropical forest in Sabah, Malaysia: a pilot study. Journal of Tropical Ecology, 28, pp 611-614 doi:10.1017/ S0266467412000624

Request Permissions : $\underline{\text { Click here }}$ 


\title{
SHORT COMMUNICATION
}

\section{The role of earthworms in nitrogen and solute retention in a tropical forest in Sabah, Malaysia: a pilot study}

\author{
Sarah Johnson*, Arshiya Bose $\dagger$, Jake L. Snaddon $\ddagger$ and Brian Moss $\S^{1}, 1$ \\ * School of Environment and Life Sciences, University of Salford, Salford, UK \\ $\dagger$ School of Geography, University of Cambridge, Cambridge, UK \\ $\ddagger$ Biodiversity Institute, Department of Zoology, University of Oxford, UK \\ $\S$ School of Environmental Sciences, University of Liverpool, Liverpool, UK \\ (Accepted 19 September 2012)
}

Key Words: conductivity, Danum valley, nitrogen, nutrient recycling, Pheretima darnleiensis, soil

Compounds of the 20 elements needed by living organisms are relatively soluble in water and therefore vulnerable to being leached and lost from terrestrial ecosystems during mineralization. Intact systems have thus acquired retention mechanisms that sequester nutrients and minimize losses. Such mechanisms should be particularly important where rainfall is very high but direct evidence of retention mechanisms in tropical forests is scarce (Snaddon et al. 2012, Turner et al. 2007).

Extensive mycorrhizal networks permeate tropical forest soils but the role of the soil invertebrate community has been only moderately investigated. Termites and ants are important but earthworms (Annelida, Clitellata, Megadrilacea) have received less attention. On the floors of some of the forests of Sabah (Borneo, Malaysia) are worm casts that are prominent tower-like structures, up to $20 \mathrm{~cm}$ or more high and $3 \mathrm{~cm}$ diameter (Figure 1), and associated with the earthworm species, Pheretima darnleiensis (Blakemore et al. 2007, Gould et al. 1987). They are made when the worms, living in the centres of the towers, systematically defecate around the upper rim. Other earthworm species are present, which produce much less structured casts and the tower-forming species is not ubiquitous. Nonetheless it is often very prominent in the forests of the Danum Valley and this suggests a major functional role. We hypothesised that the towers, built high above the general soil surface, might return nutrients from the depths of the litter layer $(5-10 \mathrm{~cm}$

\footnotetext{
${ }^{1}$ Corresponding author. Email: brmoss@liverpool.ac.uk
}

deep) and, by this modest physical recycling, decrease the risk of washout.

The work was carried out close to the Danum Valley Field Centre $\left(5^{\circ} \mathrm{N}, 118^{\circ} \mathrm{E}\right)$ (Reynolds et al. 2011). The climate is typically wet equatorial with mean annual $09 \mathrm{~h} 00$ temperature (daily records) of $26.7^{\circ} \mathrm{C}\left(\mathrm{min}=22.5^{\circ} \mathrm{C}\right.$, $\max =30.9{ }^{\circ} \mathrm{C}$ ) and mean annual rainfall of $2700 \mathrm{~mm}$ (1986-1992) (Marsh \& Greer 1992), with no discernible dry season. The terrain is rugged and the vegetation is lowland evergreen dipterocarp forest. The soils are orthic acrisols, overlying sandstones and mudstones, with 30$60 \%$ clay and $\mathrm{pH}$ of $4.0-5.3$ (Marsh \& Greer 1992).

In October 2010, five transects $(30 \mathrm{~m})$ were randomly laid down in undisturbed primary forest (two transects), secondary forest that had been selectively logged $18 \mathrm{y}$ previously, and areas that had previously been clearfelled and had very open canopies and dominance by species of ginger (Zingiberaceae). One of the latter areas was comparatively dry, the other, near a stream, was wetter. Population density of towers was determined in five quadrats $\left(0.25 \mathrm{~m}^{2}\right)$ along each transect, at randomly predetermined intervals. All towers were carefully removed for determination of fresh and dry $\left(100{ }^{\circ} \mathrm{C}\right)$ weight. Adjacent soil was also collected. In a further five random quadrats, the towers were marked with toothpicks, and the quadrats revisited and recensused after $5 \mathrm{~d}$, so that the number of new towers could be determined. A random subset of the sample of towers and adjacent soil was dried and known weights were mixed with known volumes of distilled water to dissolve solutes. The samples were then settled, and 


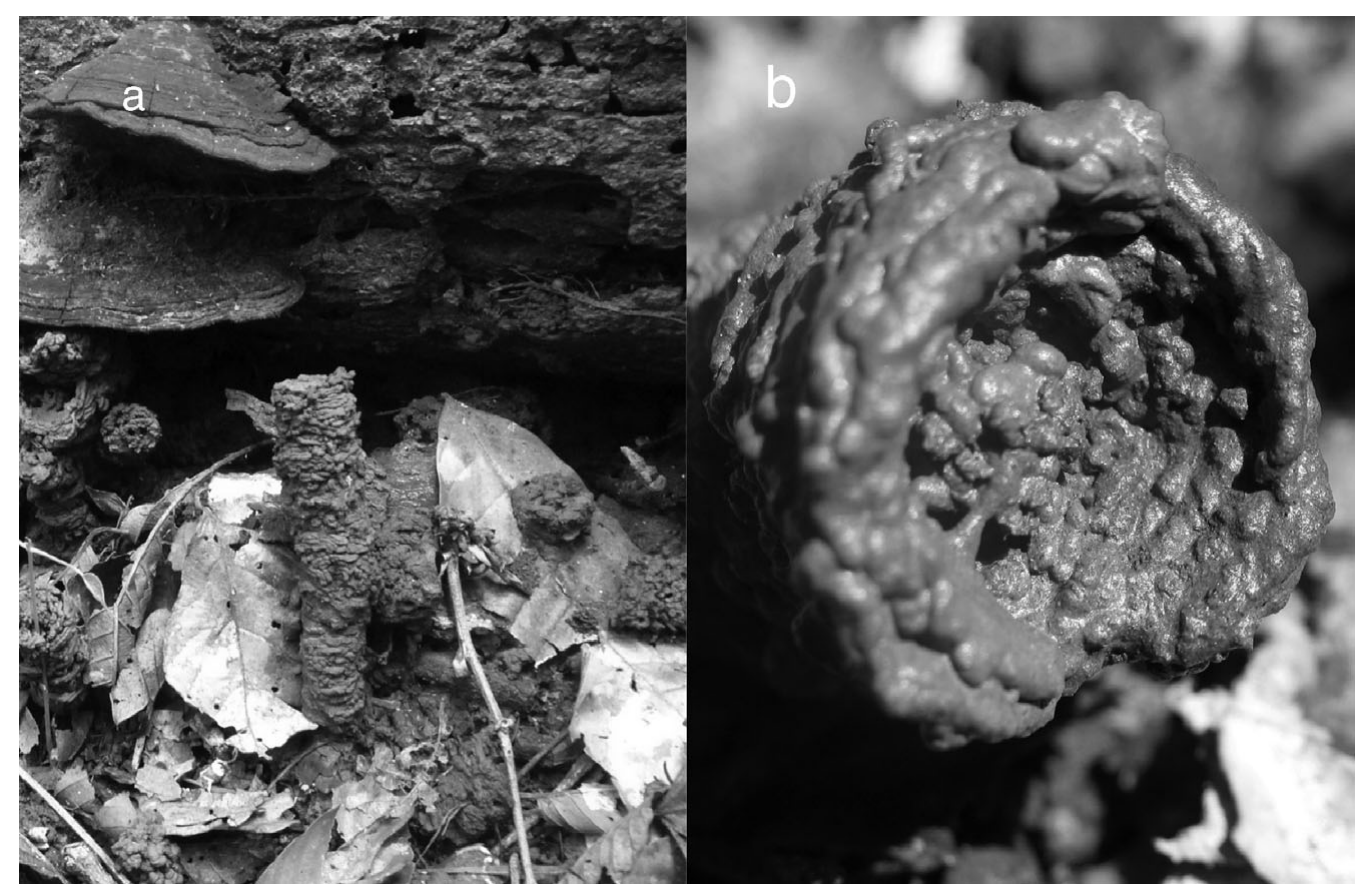

Figure 1. Towers built by earthworms in the Danum forest. A group of towers, height about $10 \mathrm{~cm}$ in front of a fallen log and surrounded by fallen leaves (a); the tip of a single tower, diameter about $3 \mathrm{~cm}$, showing the individual chains of faeces deposited around the rim by the worm (b).

the supernatant gravity-filtered through Whatman No. 1 paper filters. Conductivity and nitrate concentrations were then measured using an electronic conductivity meter (precision $\pm 10 \mu \mathrm{S} \mathrm{cm}^{-1}$, lowest detectable value $5 \mu \mathrm{S} \mathrm{cm}^{-1}$ ) and a ChemMet kit (precision $\pm 0.1 \mathrm{mg} \mathrm{L}^{-1}$ $\mathrm{NO}_{3}-\mathrm{N}$, lowest detectable value $0.05 \mathrm{mg} \mathrm{NO} \mathrm{N}_{3}-\mathrm{N} \mathrm{L}^{-1}$ ). $\mathrm{pH}$ was measured in the slurries before filtration with Merck Special Indicator ( $\mathrm{pH} 4.0-7.0) \mathrm{pH}$ sticks. The soil in 17 random quadrats, each $0.06 \mathrm{~m}^{2}$, in the primary forest was quickly dug to about $10 \mathrm{~cm}$ and the soil placed in polyethylene bags for later sorting. The number of living worms in each quadrat was determined in relation to the number of towers, which had been counted before digging.

Tower population density varied from high values in the degraded wet forest to very low values in the dry degraded forest; towers were comparatively small in the degraded forest (Table 1). Although population density was lower in the primary and secondary forests than in the wet degraded forest, this was compensated by much greater tower sizes so that total weight was not significantly different among primary, secondary and wet degraded forests. The major contrast was in the dry degraded forest where tower density, size and total weight were all low. There were significant relationships between tower population density $\left(\mathrm{m}^{-2}\right)$, weight of towers $\left(\mathrm{g} \mathrm{m}^{-2}\right)$ and the moisture content of adjacent soil. Population density of towers and water content of adjacent soil were linearly related $(r=0.59, \mathrm{P}<0.05)$. Similarly, total fresh weight of towers was logarithmically related to soil moisture content $(\mathrm{r}=0.39, \mathrm{P}<0.05)$ with towers not produced at soil moisture contents below about $18 \%$, the intercept on the first regression. The material of the towers was significantly wetter than that of adjacent soil (Table 1) and when dried, the material was harder and more difficult to pulverise than the adjacent soil, suggesting that organic glues infused it.

Table 2 shows worm activity as turnover rates of towers, based on counts of towers newly produced within $5 \mathrm{~d}$. The rate of production was assumed to follow a logarithmic function when percentage production per day was between $7 \%$ and $14.7 \%$, with high values in the primary and secondary forests, and significantly lower ones in the degraded forests. Assuming a steady state in which production equals loss, the turnover times were between 6 and $15.1 \mathrm{~d}$, with no significant differences among the primary, secondary and wet degraded forests but a significantly longer replacement time in the dry degraded forest. The ratio of number of towers to live worms was $1.75 \pm 1.03$ (but we could not be certain that all the worms dug from the quadrats were of the tower-forming species, and some may have escaped by burrowing faster than we could dig). This suggests that worms abandon their towers when some critical size is reached and begin producing a new one. Together with the data on turnover time, we calculate that a worm takes less than $4.6 \mathrm{~d}$ to produce a tower.

There were differences in the solutes extractable from the towers and from adjacent soils (Table 3). The extracts differed in $\mathrm{pH}$, with soil material slightly more 
Table 1. Density and moisture content of earthworm towers and adjacent soils. Values are mean \pm SD, $n=10$ for primary forest, 5 for other compartments. Superscript letters a, b, c refer to significant differences $(\mathrm{P}<0.05)$ in comparisons down the columns. $y$ and $\mathrm{z}$ refer to differences in moisture content along rows. Values sharing a letter are not significantly different (one-way analyses of variance).

\begin{tabular}{lccccc}
\hline & & \multicolumn{2}{c}{ Water content $(\%)$} & & \\
\cline { 3 - 4 } & No. of towers $\left(\mathrm{m}^{-2}\right)$ & Soil & Towers & Total fresh wt of towers $\left(\mathrm{g} \mathrm{m}^{-2}\right)$ & Mean fresh wt per tower $(\mathrm{g})$ \\
\hline Primary forest & $41.5 \pm 34.9^{\mathrm{a}}$ & $30.3 \pm 4.0^{\mathrm{ay}}$ & $40.7 \pm 9.3^{\mathrm{cz}}$ & $593 \pm 325^{\mathrm{a}}$ & $15.2 \pm 3.6^{\mathrm{a}}$ \\
Secondary forest & $49.6 \pm 21.2^{\mathrm{a}}$ & $25.4 \pm 1.7^{\mathrm{by}}$ & $35.7 \pm 6.0^{\mathrm{cz}}$ & $863 \pm 384^{\mathrm{a}}$ & $17.3 \pm 3.1^{\mathrm{a}}$ \\
Degraded dry & $2.8 \pm 2.2^{\mathrm{b}}$ & $21.3 \pm 4.7^{\mathrm{by}}$ & $41.5 \pm 1.1^{\mathrm{cz}}$ & $32.9 \pm 17.8^{\mathrm{b}}$ & $3.4 \pm 2.7^{\mathrm{b}}$ \\
Degraded wet & $130 \pm 53.2^{\mathrm{c}}$ & $30.0 \pm 3.7^{\mathrm{ay}}$ & $48.7 \pm 10.4^{\mathrm{cz}}$ & $1002 \pm 414^{\mathrm{a}}$ & $7.7 \pm 0.5^{\mathrm{c}}$ \\
\hline
\end{tabular}

acid than tower material, whilst there was an inverse relationship between tower population density and soil $\mathrm{pH}(\mathrm{r}=-0.63, \mathrm{P}<0.05)$ with an upper value for tower formation at about $\mathrm{pH} 5.6$ (intercept of regression line). The conductivity and nitrate concentrations in extracts of tower material were significantly higher than from adjacent soils and the ratios of conductivity to nitrate in soil and in tower material differed significantly (Table 3). There was a relative enrichment of nitrate in tower material compared with the surrounding soil, and compared with the total salt content. This suggests that the increased nitrate content was not simply a function of evaporative concentration. Nitrification may have been favoured by better oxygenation of the aerial towers.

Earthworm casts everywhere appear to accumulate mineral nutrients at higher concentrations than in surrounding soil (Parkin \& Berry 1994). Parkin \& Berry (1994), using American worms fed with nitrogenenriched agricultural soils, found casts to be enriched in mineral $\mathrm{N}$, relative to surrounding soil, and that the amount of $\mathrm{N}$ accumulated in earthworm casts (80-100 $\mathrm{mg}$ nitrate- $\mathrm{N} \mathrm{kg}^{-1}$ ) was a reflection of the $\mathrm{N}$ content of the organic matter used as a food source. In theDanum Valley, with soils that were undoubtedly poorer in nitrogen than those used by Parkin \& Berry (1994), the accumulation of nitrate in the towers was almost as great.
The earthworm towers in the Danum forest thus seem to be mineralizing and retaining much nitrogen, though we cannot entirely distinguish between absolute enrichment and increased mineralization under slightly more aerobic conditions, though the soils showed no evidence of even mildly anaerobic conditions. In the streams draining the forest, nitrate was barely or not detectable and sparseness of biofilms and invertebrate communities in the streams were consistent with this extremely low fertility (unpubl. data, B. Moss). The towers were harder to crush than the surrounding soil and this might also contribute to decreased risk of leaching of the remineralized nitrogen, thus closing the loop between leaf-litter decomposition and renewed uptake by tree roots.

The earthworms producing the towers are likely to be major 'ecosystem engineers' (Lavelle et al. 1997) in that they are probably responsible for influencing important processes of nutrient retention and regeneration. The rate of production of towers and their population densities are broadly related to wetness of the soil and because towers appear to retain nitrogen and soluble ions, in a system where heavy rainfall potentially leads to leaching of solutes, such retention may have been positively selected for in the development of the system. The inverse relationship between tower production and $\mathrm{pH}$ (reduced $\mathrm{pH}$ equating to increased leaching) is consistent with this.

Table 2. Production and turnover rates of towers. Values are mean \pm SD, $\mathrm{n}=10$ for primary forest, 5 for other compartments. Superscript letters refer to comparisons (one-way analysis of variance) down the columns. Values sharing the same letter are not significant at $\mathrm{P}=0.05$.

\begin{tabular}{lccccc}
\hline & $\begin{array}{c}\text { Initial no. of towers } \\
\left(\mathrm{m}^{-2}\right)\end{array}$ & $\begin{array}{c}\text { No. of towers 5 d later } \\
\left(\mathrm{m}^{-2}\right)\end{array}$ & $\begin{array}{c}\text { Tower production } \\
\left(5 \mathrm{~d}^{-1}\right)\end{array}$ & $\begin{array}{c}\text { Tower production rate } \\
\left(\% \mathrm{~d}^{-1}\right)\end{array}$ & Turnover time $(\mathrm{d})$ \\
\hline Primary forest & $26.4 \pm 25.2^{\mathrm{a}}$ & $39.5 \pm 34.4^{\mathrm{a}}$ & $13.1 \pm 10.0^{\mathrm{a}}$ & $10.7 \pm 5.0^{\mathrm{a}}$ & $7.6 \pm 2.9^{\mathrm{a}}$ \\
Secondary forest & $30.8 \pm 12.3^{\mathrm{a}}$ & $55 \pm 24.6^{\mathrm{a}}$ & $24.2 \pm 17.1^{\mathrm{a}}$ & $14.7 \pm 6.2^{\mathrm{a}}$ & $6.1 \pm 3.0^{\mathrm{a}}$ \\
Degraded dry & $15.4 \pm 18.2^{\mathrm{b}}$ & $18.6 \pm 23.0^{\mathrm{b}}$ & $3.2 \pm 4.9^{\mathrm{b}}$ & $7 \pm 4.5^{\mathrm{b}}$ & $15.1 \pm 10.1^{\mathrm{c}}$ \\
Degraded wet & $102 \pm 54.4^{\mathrm{c}}$ & $128 \pm 65.8^{\mathrm{c}}$ & $26.8 \pm 15.9^{\mathrm{c}}$ & $8.4 \pm 4.6^{\mathrm{b}}$ & $10.3 \pm 5.7^{\mathrm{a}}$ \\
\hline
\end{tabular}

Table 3. Comparisons between extracts of earthworm towers and soils. Values are mean $\pm \mathrm{SD}, \mathrm{n}=15$ (taken randomly from all compartments), except for the final column which is based on eight samples where the tower material and the soil were closely adjacent. Superscript letters a and $\mathrm{b}$ refer to comparisons made within columns. Superscripts $\mathrm{c}$ and d refer to a comparison along the row. Values sharing a letter are not significantly different at $\mathrm{P}=0.05 . \mathrm{pH}$ comparisons were made following conversion to $\mathrm{H}^{+}$concentration.

\begin{tabular}{lcccc}
\hline & $\mathrm{pH}(\log$ units $)$ & Conductivity $\left(\mu \mathrm{S} \mathrm{cm}^{-1} \mathrm{~kg}^{-1} \mathrm{~L}^{-1}\right)$ & Nitrate-N $\left(\mathrm{mg} \mathrm{N} \mathrm{kg}^{-1} \mathrm{~L}^{-1}\right)$ & Ratio of nitrate-N to conductivity \\
\hline Soil & $5.14 \pm 0.33^{\mathrm{a}}$ & $96.2 \pm 12.5^{\mathrm{a}}$ & $27.7 \pm 4.2^{\mathrm{a}}$ & $0.3 \pm 0.03^{\mathrm{a}}$ \\
Towers & $5.3 \pm 0.29^{\mathrm{b}}$ & $130 \pm 19.2^{\mathrm{b}}$ & $59 \pm 27.3^{\mathrm{b}}$ & $0.5 \pm 0.2^{\mathrm{b}}$ \\
Ratio soil to towers & & $0.75 \pm 0.13^{\mathrm{c}}$ & $0.46 \pm 0.27^{\mathrm{d}}$ & \\
\hline
\end{tabular}


Rapid turnover and retention of nutrients appear to be essential in maintenance of natural forest in the tropics. Where logging has exposed soils to erosion, the remaining soil is subsequently compacted, low in nutrients and organic matter, dry and hot (Nussbaum et al. 1995). It is difficult to re-establish seedlings of trees on such soils. Experiments in the Danum area (Nussbaum et al. 1995) have shown, however, that it is the shortage of nutrients that is the key limiting factor. The retention mechanisms provided by earthworms (and probably also nest-building termites), though not unique to these forests, appear particularly important. Our findings suggest that there may still be much to discover about the functioning of these forests that could be of value in guiding their management, especially after exploitation, when earthworm activity may help in maintaining nutrient-rich, moist niches for seedling establishment.

\section{ACKNOWLEDGEMENTS}

We thank the Tropical Biology Association and Dr Rosie Trevelyan for facilitating this study and the Danum Forest Field Centre and its director, Dr Glen Reynolds for providing facilities.

\section{LITERATURE CITED}

BLAKEMORE, R. J., SUZDI, C., ITO, M. T., KAWAGUCHI, T. \& SCHILTHUIZEN, M. 2007. Taxonomic status and ecology of oriental Pheretima darnleiensis (Fletcher 1886) and other earthworms
(Oligochaeta: Megascolecidae) from Mt Kinabalu, Borneo. Zootaxa 1613:23-44.

GOULD, E., ANDAU, M. \& EASTON, E. G. 1987. Observations of earthworms in Sepilok Forest, Sabah, Malaysia. Biotropica 19:370372 .

LAVELLE, P., BIGNELL, D., LEPAGE, M., WOLTERS, V., ROGER, P., INESON, P., HEA, O. W. \& DHILLION, S. 1997. Soil function in a changing world: the role of invertebrate ecosystem engineers. European Journal of Soil Biology 3:159-193.

MARSH, C. W.\& GREER, A. G. 1992. Forest land-use in Sabah, Malaysia: an introduction to Danum Valley. Philosophical Transactions of the Royal Society 335:331-339.

NUSSBAUM, R., ANDERSEN, J. \& SPENCER, T. 1995. Factors limiting the growth of indigenous tree seedlings planted on degraded forest soils in Sabah, Malaysia. Forest Ecology and Management 74:149159.

PARKIN, T. B. \& BERRY, E. C. 1994. Nitrogen transformations associated with earthworm casts. Soil Biology and Biochemistry 26:1233-1238.

REYNOLDS, G., PAYNE, J., SINUN, W., MOSIGIL, G. \& WALSH, R. D. P. 2011. Changes in forest land use and management in Sabah, Malaysian Borneo, 1990-2010, with a focus on the Danum Valley region. Philosophical Transactions of the Royal Society B 366:31683176.

SNADDON, J. L., TURNER, E. C., FAYLE, T. M., KHEN, C. V., EGGLETON, P. \& FOSTER, W. A. 2012. Biodiversity hanging by a thread: the importance of fungal litter-trapping systems in tropical rainforests. Biology Letters 8:397-400.

TURNER, E. C., SNADDON, J. L., JOHNSON, H. R. \& FOSTER, W. A. 2007. The impact of bird's nest ferns on stemflow nutrient concentration in a primary rain forest, Sabah, Malaysia. Journal of Tropical Ecology 23:721-724. 